\title{
Correspondence
}

\section{When to Attend}

Sir, - In a recent issue of Nature $(223,1186 ; 1969)$ a large number of non-Greek scientists who attended the fourth NATO Advanced Study of Molecular Biology held in Spetsai stated that thoy deplored the Greek military government but felt that it was necessary to attend this meeting so that the Greek intellectual community does not become isolated and cut off from free interchange of ideas. More recently (Nature, 224, 93; 1969) some distinguished English and French scientists (including Dr F. H. C. Crick, who was the chairman of the Spetsai meetings) gave a long analysis of the guidelines that members of the scientific community may use to help them decide what international conferences they should attend. An editorial in the same issue (Nature, 224, 2; 1969) further elaborates on the international nature of the scientific community and the independence of scientists to meet wherever they wish without having to decide on the "worthiness" of governments-provided that the scientific societies are financially independent. If a military junta (such as that in Greece) has censored the freedom of expression and has cancelled the most basic constitutional rights of its own citizens, why assume that conditions of attendance would be adhered to ? Both letters profess a deep interest in the sciontists who live in a country run by a dictatorship and a strong need to communicate with them. However, both letters neglect to point out a very crucial aspect of such meetings, and that is whether the attendance of scientists from the host country is dependent on their government's clearance. While well known scientists might be missed, promising young investigators who are not well known outside their own country could be screened and their absence at the meeting would go unnoticed.

No set of principles or guidelines can be used in deciding whether to attend a scientific meeting held in a country under an unprincipled dictatorship. Perhaps only one question is important, and that is whether, by boycotting or better still, cancelling such a meeting, this action will contribute to the unpopularity of a regime and its eventual change. In small countries, such as Greece, this is certainly very important since critical foreign opinion, including that of the international scientific community as well as economic boycott (decrease of tourism, etc.), will play an important part in the eventual removal of the military junta.

\section{Yours faithfully,}

\section{George D. Paptas}

Albert Einstein College of Medicine,

Yeshiva University,

Bronx, NY 10461.

\section{Oil Slicks and the Board of Trade}

SiR,-I would like to comment on the topic of oil pollution that was raised in your leading article (Nature, 225, 885; 1970), at least so far as concerns the United Kingdom. Following the wreck of the Torrey Canyon, the scientific and technical problems of one aspect of pollution, coastal oil pollution, were defined ${ }^{1,2}$, and in the light of the recommendations made ${ }^{3}$, coastal authorities were asked to prepare individual or joint plans to deal with this type of problem. However, such plans can only be effective when applied to the cleaning of fouled beaches, local authorities having no power or means to deal with offshore oil slicks.

To take action against oil at sea is the prerogative of the Board of Trade, the only body with the necessary powers, but one which feels quite impotent in the face of the technical problems involved. Their attitude is shown clearly in the following quotation from a reply to a question in Parliament about a recent incident. " . . searching for and dealing with a suspected oil slick would not be justified partly because there had been no sightings and a search would be very costly, and partly because dispersal at sea would have been a hazardous operation in the weather conditions prevailing. Moreover, the purpose of any action that the Board of Trade takes is to protect coastal amenities, and it has to be recognized that at this time of year (winter) not much harm is done if oil is allowed to come ashore. It is likely to be more economical to clear it up by hand there, after it has been allowed to weather...."

It is clear that a serious situation could be allowed to develop, especially in estuarine environments, unless something is done to deal with oil whilo it is still at sea. The problem with which we are faced may be illustrated by the effects of oil pollution on seabird life. Although the effects on these birds are probably unimportant relative to the problem as a whole, they are immediate and clearly visible. Moreover, dead seabird counts afford about the only units in which the relative magnitudes of coastal oil pollutions can be expressed.

As an example, a recent "routine" winter oiling along the east coast of Scotland exacted a known toll of about 8,000 seabirds, a significant proportion of which was made up by eider (Somateria mollissima). This is a slowbrceding species of which almost the whole British population winters in the Tay estuary. The population must be in great danger of extinction as a result of this incident following so closely on others in recent years ${ }^{4}$. Scaup (Aythya marila) which winter as a dense population in the Forth escaped this time, but, like the eider, their days must be numbered ${ }^{5}$. In addition to eiders, a large variety of other species was affected in the recent incident, particularly auks and divers.

I would like to emphasize that to seek out and deal with oil slicks while still at sea is not beyond the bounds of technical or economic possibility. The problem of oil pollution is a technical problem which requires a technical solution. It should not therefore be part of the responsibilities of the Board of Trade.

Yours faithfully,

64 Forfar Road,

B. POUNDER

Dundee.

${ }^{1}$ Coastal Pollution, Report from the Select Committee on Seience and Technology (HMSO, 1968).

${ }^{2}$ Torrey Canyon Pollution and Marine Life (edit. by Smith, J. E.) (Cambridge University Press, 1968).

${ }^{3}$ SDD Circular 55/1968, MHLG Cireular 34/68 (HMSO).

- Oil Pollution in the Tay Estuary following the Tank Duchess Incident, Report of l'echnical Advisory (cmmittee (Dundee Corporation, 1968). 5 Thom, V. M., Scottish Birds, 5, 417 (1969). 